\title{
PENGARUH VCT BERBANTUAN MEDIA SEDERHANA TERHADAP HASIL BELAJAR PKN
}

\author{
Ni Luh Sintya Diana Sari \\ Program Studii Pendidikan Guru Sekolah Dasar, Universitas Pendidikan Ganesha \\ sintyadianasari@gmail.com \\ Dewa Nyoman Sudana \\ Program Studii Pendidikan Guru Sekolah Dasar, Universitas Pendidikan Ganesha \\ dewanyoman.sudana@undiksha.ac.id \\ Desak Putu Parmiti \\ Program Studii Pendidikan Guru Sekolah Dasar, Universitas Pendidikan Ganesha \\ dskpt_parmiti@yahoo.co.id
}

\begin{abstract}
Abstrak
Penelitian ini bertujuan untuk mengetahui: (1) Efektivitas implementasi Value Clarification Technique (VCT) berbantuan media sederhana efektif pengaruhnya terhadap hasil belajar PKn siswa kelas III, (2) perbedaan yang signifikan antara hasil belajar PKn siswa yang mengikuti Value Clarification Technique (VCT) berbantuan media sederhana dengan siswa yang mengikuti pembelajaran konvensional di kelas III. Jenis peneltian ini adalah penelitian eksperimen semu (quasi eksperimen) dengan rancangan penelitian menggunakan desain penelitian non equivalent post-test only control group desain. Populasi penelitian ini adalah seluruh kelas III SD gugus XIV Kecamatan Buleleng Tahun Pelajaran 2017/2018 yang berjumlah 143 siswa. Sampel ditentukan dengan teknik simple random sampling dan diperoleh kelas III SD Negeri 2 Tukadmungga sebagai kelompok eksperimen yang berjumlah 24 siswa dan kelas III SD Negeri 2 Pemaron sebagai kelompok kontrol yang berjumlah 23 siswa. Data hasil belajar PKn dikumpulkan dengan metode tes yaitu tes pilihan ganda. Data dianalisis menggunakan uji t-Brunning dan Anava satu jalur. Hasil penelitian menunjukkan bahwa: (1) implementasi Value Clarification Technique (VCT) berbantuan media sederhana pengaruh terhadap hasil belajar PKn siswa kelas III dengan hasil 4,19, (2) terdapat perbedaan yang signifikan antara hasil belajar PKn siswa yang mengikuti Value Clarification Technique (VCT) berbantuan media sederhana dengan siswa yang mengikuti pembelajaran konvensional di kelas III dengan $\mathrm{F}_{\text {hitung }}=402,47>\mathrm{F}_{\text {tabel }}=4,08$. Berdasarkan hasil di atas, dapat disimpulkan bahwa Value Clarification Technique (VCT) berbantuan media sederhana berpengaruh terhadap hasil belajar PKn siswa kelas III di Gugus XIV Kecamatan Buleleng tahun pelajaran 2017/2018.
\end{abstract}

Kata kunci: VCT, media sederhana, hasil belajar

\begin{abstract}
This study aimed at discovering; 1) effectiveness of implementation Value Clarification Technique (VCT) simple mediabased towards students' civics achievement in third grade of primary schools; 2) significant difference on students' civics achievement between students taught using Value Clarification Technique (VCT) simple media-based and students taught using conventional method in third grade of primary schools. This study was a quasi-experimental study utilising non equivalent post-test only control group design. The population of this study was all third graders of Buleleng district cluster XIV primary schools consisting of 143 students. The samples of this study were 24 students from third grade of SDN 2 Tukadmungga as experimental group and 23 students from third grade of SDN 2 Pemaron as control group. The samples were chosen using simple random sampling technique. Data of students' civics achievement were collected through multiplechoice test. Data analysis in this study were Brunning t-test and one-way ANOVA. The results of the study show that; 1) Value Clarification Technique (VCT) simple media-based gives an effective effect to students' civics achievement in third grade of primary schools with the score $4.19 ; 2$ ) there is a significant difference o students' civics achievement between students taught using Value Clarification Technique (VCT) simple media-based and students taught using conventional method in which F observed $=402.47>\mathrm{F}$ critical value $=4.08$. It indicates that Value Clarification Technique $(\mathrm{VCT})$ simple media-based gives an effect towards students' civics achievement in third grade of Buleleng district cluster XIV primary schools academic year 2017/2018.
\end{abstract}

Key words: civics achievement, simple media, VCT

\section{Pendahuluan}

Pada jenjang pendidikan di sekolah dasar mata pelajaran yang memiliki peranan yang cukup besar dalam kehidupan sehari-hari adalah mata pelajaran PKn. Hakim (2016) menyatakan pendidikan kewarganegaraan sangat diperlukan karena sebagai wahana pendidikan dalam membina kesadaran siswa terhadap hak dan kewajiban berdasarkan pada jiwa dan nilai-nilai bangsa Indonesia. Siswa diharapkan memiliki wawasan berbangsa dan bernegara, sikap cinta tanah air, dan ketahanan nasional. Mardenis (2017:12) menyatakan "pendidikan kewarganegaraan perannya sangat penting dalam upaya membangun watak bangsa yang saat ini tengah dilanda oleh krisis multidimensi, termasuk krisis kepribadian”. Kepribadian yang diharapkan dimiliki 
siswa adalah religius, humanis, nasionalis, demokratis, dan sosialis. Menurut Susanto (2013) menyatakan pendidikan kewarganegaraan adalah mata pelajaran yang digunakan untuk mengembangkan dan melestarikan nilai luhur dan moral siswa tetapi tetap berlandaskan pada budaya bangsa Indonesia.

Permendiknas Nomor 22 tahun 2006 tentang Standar Isi untuk Satuan Pendidikan Dasar dan Menengah tujuan PKn yaitu "untuk meningkatan kesadaran dan wawasan peserta didik akan status, hak, dan kewajibannya dalam kehidupan bermasyarakat, berbangsa, dan bernegara.serta peningkatan kualitas dirinya sebagai manusia". Oleh karena itu, sudah seharusnya PKn di SD mampu memberikan pengetahuan tentang nilai-nilai bagi siswa sehingga siswa tidak hanya sekedar memahami, tetapi juga dapat menerapkan dan mengamalkan nilai-nilai yang didapat dari pembelajaran PKn dalam kehidupan sehari-hari. Proses pembelajaran di kelas sebaiknya dirancang agar menjadi lebih menarik, sehingga siswa merasa senang, gembira, dan tidak merasa tertekan atau terpaksa dalam belajar PKn. Selain itu, pembelajaran PKn hendaknya dapat menjadikan siswa lebih aktif dalam proses pembelajaran agar dapat mengoptimalkan kemampuan dan pengetahuan yang dimiliki oleh siswa. Jika siswa sudah tertarik belajar PKn maka nilai luhur dan moral dapat dipahami dan diterapkan oleh siswa dengan baik. Sehingga kelak siswa akan menjadi manusia yang cerdas, bersikap baik, mampu mengikuti kemajuan teknologi tetapi tetap berpijak pada budaya bangsa.

Pada kenyataanya, pelaksanaan proses pembelajaran PKn belum maksimal. Hal ini sangat terlihat dalam proses pembelajaran atau pengemasan pembelajaran PKn yang masih bersifat hafalan dan tidak mengkombinasikan dengan model-model pembelajaran yang bersifat inovatif, sehingga proses pembeljaran PKn terkesan monoton. Berdasarkan wawancara pada tanggal 24 November 2017 dengan beberapa guru PKn di SD Gugus XIV Kecamatan Buleleng Kabupaten Buleleng yang telah dilakukan, diperoleh informasi mengenai kendala yang menyebabkan rendahnya hasil belajar PKn siswa diantaranya; (1) guru menyatakan dalam proses pembelajaran di kelas guru tidak menggunakan model, (2) saat menyampaikan materi guru tidak menggunakan media pembelajaran, karena menggunkan media pembelajaran memerlukan waktu untuk membuatnya dan memerlukan biaya yang mahal jika membelinya.

Selain wawancara, dilakukan juga observasi pada saat proses pembelajaran berlangsung pada tanggal 24 november 2017 ditemukan beberapa permasalahan dalam proses pembelajarannya diantaranya; (1) dalam proses pembelajaran guru tidak menerapkan model pembelajaran inovatif. Saat melakukan kegiatan belajar mengajar guru lebih banyak menerapkan teacher center. Ketika guru memberikan tanya jawab hanya beberapa orang siswa saja yang menjawab pertanyaan dari guru, sedangkan yang lain hanya mendengar dan mencatat informasi yang disampaikan oleh temannya. Proses pembelajaran seperti ini terjadi karena tidak adanya kreativitas yang dilakukan oleh guru untuk ikut melibatkan siswa dalam proses pembelajaran. Hal ini diperkuat oleh pernyataan Susanto (2013) menyatakan bahwa daya tarik terhadap pelajaran PKn masih lemah, karena membosankan dan cenderung tidak disukai siswa karena materi dan metodenya tidak menantang siswa secara intelektual, (2) saat guru menerangkan, ada beberapa siswa yang ribut dengan teman sebangkunya. Siswa yang berbicara dengan teman sebangkunya ketika guru menerangkan tidak akan dapat menyerap materi yang di sampaikan oleh guru dengan baik. Suara gaduh yang dihasilkan juga dapat mengurangi konsentrasi karena dalam menerima suatu materi diperlukan suasana belajar yang kondusif, (3) selama proses pembelajaran berlangsung tidak terlihat adanya penggunaan media pembelajaran. Padahal media sangat diperlukan untuk membantu agar siswa tidak berpikir abstrak. Selama proses pembelajaran yang digunakan hanya buku ajar.

Catatan dokumen yang diperoleh di SD Gugus XIV Kecamatan Buleleng Kabupaten Buleleng berupa nilai Ulangan Akhir Semester (UAS). Data menunjukkan bahwa hasil belajar PKn siswa kelas III di SD Gugus XIV Kecamatan Buleleng Kabupaten Buleleng masih rendah. Hal ini dibuktikan dengan nilai UAS siswa yang berada dibawah KKM. Rendahnya nilai UAS siswa dapat dilihat pada tabel 1.1 sebagai berikut.

Tabel 1. Nilai Rata-Rata Ulangan Akhir Semester Mata Pelajaran Pkn Siswa Kelas III di SD Gugus VIX Kecamatan Buleleng Kabupaten Buleleng

\begin{tabular}{cccccccc}
\hline No & Nama Sekolah & $\begin{array}{c}\text { Jumlah } \\
\text { Siswa }\end{array}$ & KKM & $\begin{array}{c}\text { Siswa yang } \\
\text { mencapai } \\
\text { KKM }\end{array}$ & $\begin{array}{c}\text { Siswa yang } \\
\text { mencapai } \\
\text { KKM (\%) }\end{array}$ & $\begin{array}{c}\text { Siswa yang } \\
\text { belum } \\
\text { mencapai } \\
\text { KKM }\end{array}$ & $\begin{array}{c}\text { Siswa yang } \\
\text { belum } \\
\text { mencapai } \\
\text { KKM (\%) }\end{array}$ \\
\hline 1 & SDN 1 Pemaron & 38 & 70 & 12 & $28,94 \%$ & 27 & $71,06 \%$ \\
\hline 2 & SDN 2 Pemaron & 23 & 70 & 8 & $34,78 \%$ & 15 & $65,22 \%$ \\
\hline 3 & $\begin{array}{c}\text { SDN 1 } \\
\text { Tukadmunga }\end{array}$ & 37 & 70 & 8 & $21,62 \%$ & 29 & $78,38 \%$ \\
\hline 4 & $\begin{array}{c}\text { SDN 2 } \\
\text { Tukadmungga }\end{array}$ & 24 & 70 & 9 & $37,50 \%$ & 15 & $62,50 \%$ \\
\hline 5 & $\begin{array}{c}\text { SDN 3 } \\
\text { Tukadmungga }\end{array}$ & 21 & 70 & 6 & $28,57 \%$ & 15 & $71,43 \%$ \\
\hline & Total & $\mathbf{1 4 3}$ & $\mathbf{7 0}$ & $\mathbf{4 2}$ & $\mathbf{3 0 , 2 8 \%}$ & $\mathbf{1 0 1}$ & $\mathbf{6 9 , 7 2 \%}$ \\
\hline
\end{tabular}


Nilai ulangan akhir semester ganjil pada tabel 1.1 menunjukkan bahwa jumlah siswa yang belum mencapai KKM sebanyak 101 orang dan jumlah siswa yang mencapai KKM sebanyak 42 orang. Persentase siswa yang sudah mencapai KKM yaitu 30,28\% dan yang belum mencapai KKM yaitu 69,72\%. Setelah dibandingkan ternyata didapatkan bahwa siswa yang belum mencapai KKM lebih tinggi persentasenya dari pada siswa yang sudah mencapai KKM. Ini berarti hasil belajar PKn siswa dinyatakan masih rendah.

Salah satu alternatif yang dilakukan untuk meningkatkan hasil belajar PKn siswa kelas III di SD Gugus VIX Kecamatan Buleleng Kabupaten Buleleng dengan menggunakan Value Clarification Techniqe (VCT). Menurut Sanjaya (2006:283) "Value Clarification Technique (VCT) merupakan teknik pengajaran untuk membantu siswa dalam mencari dan menentukan suatu nilai yang dianggap baik, kemudian nilai tersebut digunakan dalam menghadapi suatu persoalan melalui proses menganalisis nilai yang sudah ada dan tertanam dalam diri siswa". Guru memberikan stimulus kepada siswa untuk menentukan suatu nilai, kemudian nilai tersebut dianalisis untuk memperoleh target nilai yang kemudian diterapkan dalam kehidupan sehari-hari. VCT mampu menciptakan proses pembelajaran yang interaktif, inspiratif, menyenangkan, menantang, dan memotivasi siswa untuk ikut aktif dalam proses pembelajaran. Wahyuni (2014) menyatakan dalam praktik pembelajaran, VCT dikembangkan melalui proses dialog antara guru dan siswa. Proses tersebut berlangsung dalam suasana santai dan terbuka, sehingga setiap siswa dapat mengungkapkan secara bebas pendapatnya. Sejalan dengan pendapat tersebut, Djahiri (dalam Taniredja, 2011:91) menyatakan "Value Clarification Technique (VCT) memiliki keunggulan yaitu: (a) mampu membina dan menanamkan nilai dan moral pada ranah internal side; (b) mampu mengklarifikasi/ menggali dan mengungkapkan isi pesan materi yang disampaikan sehingga akan memudahkan guru untuk menyampaikan makna/ pesan nilai/ moral; (c) mampu mengklarifikasi dan menilai kualitas nilai moral diri siswa, melihat nilai yang ada pada orang lain dan memahami nilai moral yang ada dalam kehidupan nyata; (d) mampu mengundang, melibatkan, membina, dan mengembangkan potensi diri siswa terutama mengembangkan potensi sikap; (e) mampu memberikan sejumlah pengalaman belajar dari berbagai kehidupan; (f) Mampu menangkal, meniadakan, mengintervensi, dan memadukan berbagai nilai moral dalam sistem nilai dan moral yang ada dalam diri seseorang; (g) Memberi gambaran nilai moral yang patut diterima dan menuntun serta memotivasi untuk hidup layak dan bermoral.

Proses pembelajaran di kelas akan lebih optimal apabila didukung dengan penggunaan media. Penggunaan media pembelajaran dapat membantu siswa untuk lebih mudah memahami materi pembelajaran. Salah satu media yang mendukung kegiatan belajar mengajar adalah media sederhana. Media sederhana akan membuat suasana belajar lebih menarik sehingga siswa dapat aktif dalam proses pembelajaran di dalam kelas. Oleh karena itu, mengkombinasikan Value Clarification Technique (VCT) dengan media sederhana diharapkan dapat meningkatkan hasil belajar siswa.

Berdasarkan latar belakang di atas maka peneliti memilih judul Pengaruh Value Clarification Technique (VCT) Berbantuan Media Sederhana Terhadap Hasil Belajar PKn Siswa Kelas III di Gugus XIV Kecamatan Buleleng Kabupaten Buleleng Tahun Pelajaran 2017/2018.

\section{Metode}

Penelitian ini dilaksanakan di SD yang ada di Gugus XIV Kecamatan Buleleng Kabupaten Buleleng Tahun Pelajaran 2017/2018. Penelitian ini merupakan penelitian eksperimen semu (quasi eksperiment). Karena tidak semua variabel yang muncul dan kondisi eksperimen dapat diatur dan dikontrol secara ketat. Penelitian ini menggunakan rancangan non equivalent post-test only control group desain. Secara procedural desain penelitian ini disajikan dalam tabel 2 sebagai berikut.

Tabel 2. Desain Penelitian

\begin{tabular}{ccc}
\hline Kelompok & Perlakuan & Post-tes \\
\hline Eksperimen & $\mathrm{X}_{1}$ & $\mathrm{Q}_{1}$ \\
\hline Kontrol & $\mathrm{X}_{2}$ & $\mathrm{Q}_{2}$
\end{tabular}

Keterangan:

$\mathrm{X}_{1} \quad$ : Perlakuan pembelajaran Value Clarification Technique (VCT) (Kelompok Eksperimen)

$\mathrm{X}_{2}$ : Perlakuan tidak menggunakan pembelajaran Value Clarification Technique (VCT) (Kelompok Kontrol)

$\mathrm{Q}_{1} \quad$ : Tes akhir (post-test) kelompok eksperimen

$\mathrm{Q}_{2} \quad$ : Tes akhir (post-test) kelompok kontrol

Populasi dalam penelitian ini adalah seluruh kelas III yang ada di SD Gugus XIV Kecamatan Buleleng Kabupaten Buleleng yang berjumlah 143 siswa. Sebelum menentukan kelas sampel, terlebih dahulu dilakukan uji kesetaraan terhadap populasi penelitian untuk mengetahui apakah kemampuan siswa di masing-masing gugus 
setara atau belum. Uji kesetaraan dilakukan dengan menggunakan analisis varian satu jalur (Anava A). Berdasarkan hasil uji kesetaraan menggunakan ANAVA A, diperoleh seluruh populasi setara. Selanjutnya, untuk menentukan kelas eksperimen dan kelas kontrol dilakukan dengan teknik sampling. Teknik sampling yang digunakan yaitu teknik simple random sampling. Menurut Sugiono (2017:120) dikatakan simple (sederhana) karena "pengambilan anggota sampel dari populasi dilakukan secara acak tanpa memperhatikan strata yang ada dalam populasi itu". Simple random sampling pada penelitian ini dilakukan dengan cara pengundian. Pengundian sampel dilakukan pada semua sekolah yang ada di Gugus XIV Kecamatan Buleleng Kabupaten Buleleng, karena setiap sekolah mendapatkan kesempatan yang sama untuk menjadi sampel. Semua sekolah populasi dirandom untuk menentukan dua sekolah sebagai kelas eksperimen dan kelas kontrol.

Berdasarkan pengundian yang telah dilakukan, Berdasarkan simple random sampling yang telah dilakukan, maka SD Negeri 2 Tukadmungga sebagai kelompok eksperimen yang mendapat Value Clarification Technique (VCT) berbantuan media sederhana dan SD Negeri 2 Pemaron sebagai kelompok kontrol yang mendapat perlakuan pembelajaran konvensional. Siswa pada kelas eksperimen berjumlah 24 orang dan siswa pada kelas kontrol berjumlah 23 orang. Total jumlah sampel dalam penelitian ini adalah 47 orang.

Metode pengumpulan data dalam penelitian ini menggunakan metode tes. Tes yang digunakan adalah tes pilihan ganda.Teknik analisis data yang digunakan adalah teknik analisis deskriptif untuk mencari nilai hasi belajar PKn dengan menghitung mean, median, modus, standar deviasi, dan varians terhadap masing-masing kelompok. Mean, median, modus kemudian disajikan ke dalam poligon. Penentuan tinggi rendahnya variabelvariabel penelitian dapat ditentukan dari nilai rata-rata tiap-tiap variabel yang dikonvensikan ke dalam PAP skala Lima. Teknik analisis statistik inferensial yang digunakan adalah uji t-Brunning dan Anava Satu jalur. Sebelum melakukan uji hipotesis, terlebih dahulu dilakukan analisis uji prasyarat yang meliputi uji normalitas dan uji homogenitas.

\section{Hasil dan Pembahasan}

Data hasil penelitian ini yaitu nilai hasil belajar PKn siswa yang diperoleh melalui post-tets. Deskripsi hasil belajar PKn memaparkan nilai rata-rata, mean, median, modus, standar deviasi, dan varians. Deksripsi data keterampilan berbicara disajikan pada tabel 3 .

Tabel 3. Deskripsi Nilai Hasil Belajar PKn

\begin{tabular}{ccc}
\hline Hasil Analisis & Kelompok Eksperimen & Kelompok Kontrol \\
\hline Mean & 79,38 & 50,78 \\
\hline Median & 80,75 & 49,57 \\
\hline Modus & 82,50 & 47,64 \\
\hline Varians & 23,64 & 24,09 \\
\hline Standar Deviasi & 4,86 & 4,91 \\
\hline
\end{tabular}

Mean, median, modus hasil belajar PKn selanjutnya disajikan kedalam kurva polygon. Tujuan dalam penyajian data ini yaitu untuk menafsirkan sebaran data hasil belajar PKn siswa. Hubungan antara mean (M), median (Me), dan modus (Mo) untuk menentukan kemiringan kurva polygon distribusi frekuensi.

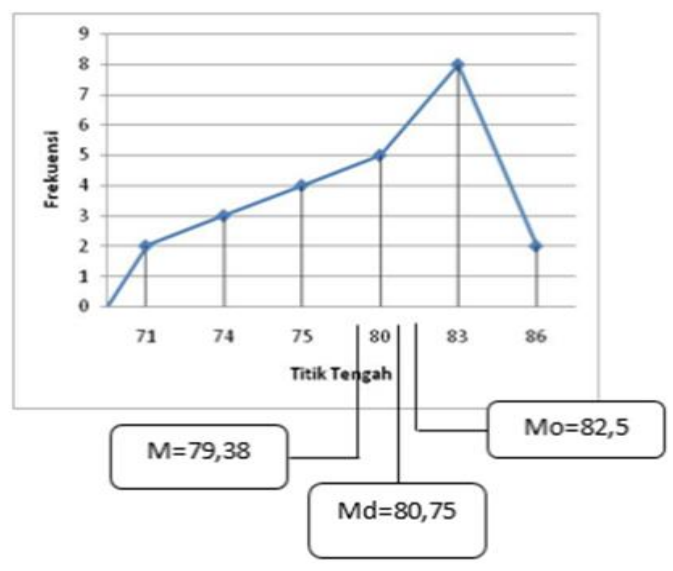

Gambar 1. Grafik Polygon Nilai Hasil Belajar Kelompok Eksperimen 
Berdasarkan grafik poligon nilai hasil belajar kelompok eksperimen di atas, dapat diketahui bahwa modus lebih besar dari median dan median lebih besar dari mean (Mo $>M d>M)$. Dengan kata lain, grafik di atas adalah grafik juling negatif. Artinya, sebagian besar nilai cenderung tinggi. Jika dikonvensikan ke dalam PAP skala Lima hasil belajar siswa kelompok eksperimen berada pada kriteria "Sangat Tinggi"

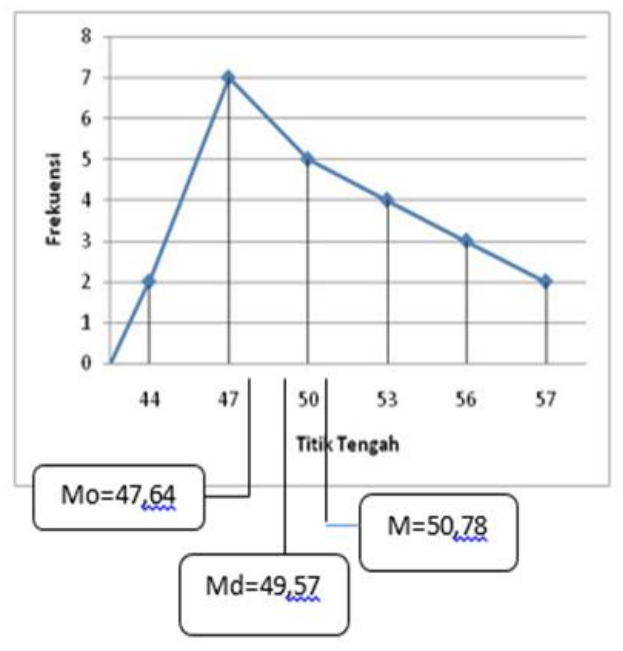

Gambar 2 Hasil Belajar Kelompok Kontrol

Berdasarkan gambar di atas, data hasil belajar PKn kelompok kontrol dapat diketahui bahwa modus lebih kecil dari median dan median lebih kecil dari mean $(\mathrm{Mo}<\mathrm{Md}<\mathrm{M})$. Dengan kata lain, grafik di atas menunjukkan kurva juling positif. Artinya, sebagian besar nilai cenderung rendah. Jika dikonversikan ke dalam PAP skala Lima hasil belajar PKn siswa kelompok kontrol berada pada kategori "Sedang".

Dari data tersebut menunjukkan bahwa kelompok ekspeimen yang dibelajarkan dengan menggunakan Value Clarification Technique (VCT) berbantuan media sederhana memiliki nilai rata-rata lebih tinggi dibandingkan kelompok kontrol yang dibelajarkan dengan pembelajaran konvensional. Sebelum dilanjutkan pada pengujian hipotesis, terlebih dahulu dilakukan pengujian asumsi terhadap data yang diperoleh meliputi uji normalitas sebaran data dan uji homogenitas varians.

Berdasarkan hasil perhitungan dengan menggunakan uji Chi-kuadrat $\left(X^{2}\right)$ diperoleh $X^{2}{ }_{\text {hitung }}$ hasil post-test hasil belajar PKn kelompok eksperimen adalah 3,691 dan $X^{2}$ tabel dengan taraf signifikansi 5\% dan db 3 adalah 7,815. Hal ini berarti, $X^{2}$ hitung hasil post-test kelompok eksperimen lebih kecil dari $X^{2}{ }_{\text {tabel }}\left(X^{2}{ }_{\text {hitung }}<X^{2}\right.$ tabel), sehingga nilai hasil belajar PKn kelompok eksperimen berdistribusi normal.

Sedangkan, untuk post-test hasil belajar kelompok kontrol, diperoleh $X^{2}$ hitung adalah 2,531 taraf signifikansi $5 \%$ dan $\mathrm{db}=3$ adalah 7,815. Hal ini berarti, $X^{2}$ hitung post-test kelompok kontrol lebih kecil dari $X^{2}$ tabel $\left(X^{2}{ }_{\text {hitung }}<X^{2}\right.$ tabel $)$, sehingga nilai hasil belajar PKn kelompok kontrol berdistribusi normal.

Uji homogentias dilakukan terhadap varians pasangan antar kelompok eksperimen dan kontrol. Uji yang dilakukan adalah uji-F dengan kriteria data homogen jika $F_{\text {hitung }}<\mathrm{F}_{\text {tabel. }}$ Berdasarkan perhitungan dari uji homogenitas didapatkan $F_{\text {hitung }}=1,02$. Sedangkan nilai $F_{\text {tabel }}$ dengan $\mathrm{db}_{\text {pembilang }}=24-1=23, \mathrm{db}_{\text {penyebut }}=23-1=22$, dan taraf signifikansi 5\% adalah 2,05. Hal ini berarti $\mathrm{F}_{\text {hitung }}<\mathrm{F}_{\text {tabel }}$ yang berarti, H1 diterima dan H0 ditolak. Sehingga varians data hasil belajar PKn kelompok eksperimen dan kontrol adalah homogen.

Pengujian hipotesis dilakukan menggunakan uji t-Brunning dan Anava Satu Jalur. Pada uji hipotesis 1 menggunakan uji t-Brunning untuk mengetahui apakah implementasi value clarification technique (VCT) berbantuan media sederhana efektif atau tidak pengaruhnya terhadap hasil belajar PKn siswa kelas III di Gugus XIV. Hasil perhitungan uji t-Brunning disajikan pada tabel 4.

Tabel 4. Hasil Perhitungan uji t-Brunning

\begin{tabular}{ccccc}
\hline Data & Kelompok & N & $\begin{array}{c}\text { Efektivitas Size } \\
(\text { ES })\end{array}$ & Kriteria Tingkat Efektivitas Size (ES) \\
\hline $\begin{array}{c}\text { Hasil } \\
\text { Belajar PKn }\end{array}$ & Eksperimen & 24 & 4,19 & $0,8<$ ES -------- efektivitas tinggi \\
\hline
\end{tabular}

Berdasarkan tabel 4, dapat diketahui hasil perhitungan uji t-Brunning menunjukkan efektivitas size (ES) 4,19. Ini berarti termasuk kedalam efektivitas tinggi $(0,8<4,19)$. Maka HO ditolak dan H1 diterima. Artinya, terdapat efektifivitas implementasi Value Clarification Technique (VCT) berbantuan media sederhana efektif pengaruhnya tjerhadap hasil belajar PKn siswa kelas III di gugus XIV kecamatan buleleng kabupaten buleleng tahun pelajaran 2017/2018. 
Pada uji hipotesis 2 menggunakan Anava Satu Jalur untuk mengetahui terdapat atau tidak perbedaan yang signifikan terhadap hasil belajar PKn siswa yang mengikuti Value Clarification Technique (VCT) berbantuan media sederhana dengan siswa yang mengikuti pembelajaran konvensional di kelas III di Gugus XIV. Hasil perhitungan uji Anava Satu Jalur disajikan pada tabel 5.

Tabel 5. Hasil Perhitungan Uji Anava Satu Jalur

\begin{tabular}{cccccccc}
\hline $\begin{array}{c}\text { Sumber } \\
\text { Variasi }\end{array}$ & Jk & db & RJK & Fh & \multicolumn{2}{c}{ F tab } & \multirow{2}{*}{ Ket } \\
\cline { 1 - 3 } & & & & & $\mathbf{5 \%}$ & $\mathbf{1 \%}$ & \\
\hline Antar A & 9601,57 & 1 & 9601,57 & 402,47 & 4,08 & 7,31 & Antar A \\
\hline Dalam & 1073,54 & 45 & 23,86 & - & - & - & Dalam \\
\hline Total & 10675,11 & 47 & - & - & - & - & Total \\
\hline
\end{tabular}

Berdasarkan tabel di atas, dapat diketahui $\mathrm{f}_{\text {hit }}=402,47$ dan $\mathrm{t}_{\text {tab }}=4,08$ untuk taraf signifikansi $5 \%$. Berdasarkan kriteria pengujian, karena $\mathrm{F}_{\text {hit }}>\mathrm{F}_{\text {tab }}$ maka $\mathrm{H}_{0}$ ditolak dan $\mathrm{H}_{1}$ diterima. Artinya, terdapat pengaruh signifikan hasil belajar PKn antara siswa yang mengikuti Value Clarification Technique (VCT) berbantuan media sederhana siswa yang mengikuti pembelajaran konvensional di kelas III di gugus XIV kecamatan buleleng kabupaten buleleng tahun pelajaran 2017/2018.

(1) Pembahasan tentang implementasi Value Clarification Technique (VCT) berbantuan media sederhana efektif pengaruhnya terhadap hasil belajar PKn siswa kelas III di gugus XIV kecamatan buleleng kabupaten buleleng tahun pelajaran 2017/2018. Hasil analisis dalam penelitian ini pada uji T-Brunning menunjukkan bahwa implementasi Value Clarification Technique (VCT) berbantuan media gambar efektif pengaruhnya terhadap hasil belajar PKn siswa kelas III pada siswa kelompok eksperimen termasuk kedalam kriteria efektivitas tinggi $(0,8<4,19)$. Hal ini dikarenakan siswa dilatih berpikir kritis untuk menganalisis suatu nilai. Nilai awal yang dipilih siswa kemudian dianalisis kembali sehingga akan muncul nilai yang positif. Dalam proses menganalisis nilai ini, siswa dilatih untuk berpikir kristis dan berani mempertanggung jawabkan nilai yang sudah dipilihnya. Nilai tersebut diharapkan dapat diterapkan dalam kehidupan siswa. Hal ini sejalan dengan Adisusilo (2012:155) menyatakan Value Clarification Technique (VCT) adalah "melatih peserta didik untuk berproses melakukan penilaian terhadap nilai-nilai kehidupan yang ada di dalam masyarakat, dan akhirnya menetapkan nilai yang menjadi acuan hidupnya". Contohnya pada materi bangga menjadi bangsa Indonesia. Siswa diberikan rangsanganoleh guru. Siswa diminta untuk ikut terlibat memberikan pendapat dan alasan memilih nilai tersebut. Kemudian nilai yang sudah dipilih siswa dianalisis kembali untuk mendapatkan nilai yang baik. Hal ini akan memudahkan siswa menerapkan nilai yang diberikan karena siswa mendapatkan nilai tersebut dari proses memahami bukan hafalan.

Adanya bantuan media membantu siswa tidak berpikir abstrak dan menyebabkan siswa lebih tertarik untuk mengikuti proses pembelajaran. Media yang digunakan adalah media sederhana karena, media sederhana adalah media yang mudah ditemukan. Hal ini sejalan dengan pendapat Tegeh (2010:28) menyatakan media sederhana bahan dasarnya mudah diperoleh dan harganya murah, cara pembuatannya mudah, dan penggunaannya tidak sulit. Media sederhana yang digunakan berupa gambar. Menurut Subana dan Sunarti (2002:325) menyatakan kelebihan media gambar adalah harganya murah, mudah digunakan karena tidak membutuhkan peralatan. Gambar yang diperlihatkan oleh guru akan membantu siswa mengkronkretkan bendabenda yang masih bersifat abstrak. Contohnya ketika belajar materi "Bangga menjadi Anak Indonesia". Pada materi ini salah satunya siswa diajarkan tentang alat musik tradisional di Indonesia. Salah satu contoh musik tradisional di Indonesia adalah Sasando yang berasal dari Nusa Tenggara Timur yang memainkannya dengan cara dipetik. Banyak siswa yang tidak tahu bentuk Sasando. Dengan adanya media sederhana berupa gambar, maka siswa akan menjadi tahu seperti apa bentuk dari Sasando. Siswa tidak perlu lagi berpikir abstrak bagaimana bentuk dari Sasando tersebut. Apalagi karakteristik siswa SD belum dapat berpikir secara abstrak. Karena siswa SD berada pada jenjang operasional konkret (7-11 tahun). Hal ini sejalan dengan pendapat Piaget (dalam Karwono dan Heni, 2017:89) yang menyatakan "dalam tahap operasional konkret individu sudah mengembangkan pemikiran logis untuk menggantikan pemikiran intuitif, tetapi hanya dalam situasi yang konkret. pemikiran operasional konkret adalah tindakan mental yang bisa bolak balik yang berkaitan dengan objek yang nyata dan konkret. Anak sudah dapat menarik simpulan berdasarkan logika meskipun masih terbatas pada benda-benda yang konkret. Anak belum dapat memecahkan masalah yang abstrak". Selain itu dengan adanya media sederhana siswa terlihat antusias dan senang dalam mengikuti proses pembelajaran. Keterlibatan langsung siswa dalam pembelajaran dapat terlihat pada saat siswa berinteraksi memberikan jawaban maupun tanggapan. Hal ini terlihat ketika ada siswa yang maju ke depan kelas untuk menyampaikan alasan memilih nilai pilihannya, siswa yang lain terlihat ikut memberikan tanggapan. Semakin sering siswa ke depan kelas untuk menyampaikan jawaban maka akan menumbuhkan sikap percaya diri pada siswa. Siswa yang memiliki sikap percaya diri akan merasa sanggup menghadapi tantangan. Tantangan dalam hal ini adalah berupa pertanyaan- 
pertanyaan yang diberikan dari guru maupun siswa yang lain sehingga berdampak pada kemampuan kognitif siswa. Selain itu siswa yang berani maju ke depan kelas mendapatkan reward sehingga merangsang siswa yang lain berlomba-lomba maju ke depan kelas untuk menyampaikan pendapatnya.

(2) Pembahasan tentang perbedaan hasil belajar PKn siswa yang mengikuti Value Clarification Technique (VCT) berbantuan media sederhana dengan siswa yang mengikuti pembelajaran konvensional di kelas III di gugus XIV kecamatan buleleng kabupaten buleleng tahun pelajaran 2017/2018. Berdasarkan analisis data pada uji ANAVA A. diketahui, fhit $=402,47$ dan ttab $=4,08$ untuk taraf signifikansi 5\%. Berdasarkan kriteria pengujian, karena Fhit > Ftab maka H0 ditolak dan H1 diterima. Artinya, terdapat perbedaan yang signifikan terhadap hasil belajar PKn siswa yang mengikuti Value Clarification Technique (VCT) berbantuan media sederhana dengan siswa yang mengikuti pembelajaran konvensional di kelas III di gugus XIV kecamatan buleleng kabupaten buleleng tahun pelajaran 2017/2018.

Berdasarkan rata-rata nilai hasil belajar siswa yang mengikuti Value Clarification Technique (VCT) berbantuan media sederhana adalah 79,38 dan rata-rata nilai hasil belajar siswa yang mengikuti pembelajaran konvensional adalah 50,78. Hal ini menunjukkan bahwa hasil belajar siswa yang mengikuti Value Clarification Technique (VCT) berbantuan media sederhana lebih tinggi dibandingkan dengan siswa yang mengikuti pembelajaran konvensional.

Pembelajaran menggunakan Value Clarification Technique (VCT) guru lebih banyak bertugas memberikan rangsangan. Rangsangan yang diberikan guru berupa stimulus. Guru memberikan stimulus berupa pertanyaan-pertanyaan yang memotivasi siswa untuk belajar. Contohnya siswa diperlihankan gambar oleh guru. Kemudian guru memberikan stimulus menurut kalian dari 2 gambar ini manakah yang menunjukkan cinta terhadap bangsa Indonesia? Siapa yang melih A atau B? Mengapa kalian memilih gambar A atau B? Apakah kalian tahu apa dampak positif dan negatif dari gambar A atau B?. Dengan adanya stimulus akan mendorong siswa untuk berpikir sehingga akan memunculkan rasa ingin tahu dalam diri siswa untuk merespon jawaban dari pertanyaan yang diberikan oleh guru. Ketika merespon, jawaban yang diberikan siswa benar maka akan timbul rasa senang dalam diri siswa. Sedangkan ketika merespon, jawaban yang diberikan siswa salah, maka akan memunculkan keinginan untuk memperbaiki kesalahannya dengan usaha yang baru dengan cara membaca, tutor dengan teman sebaya, atau menggali kembali pengetahuan yang dimilikinya. Proses pembelajaran seperti ini terjadi berulang sehingga dapat membuat siswa aktif di dalam proses pembelajaran di dalam kelas. Ketika siswa bertanya maupun merespon pertanyaan yang diberikan oleh guru, berarti siswa memusatkan perhatiannya terhadap materi yang diberikan. Jika pikiran siswa sudah terpusat pada materi, maka akan mempermudah terjadinya kegiatan belajar-mengajar di kelas. Materi yang diterima siswa akan mudah diterima karena melalui memahami bukan hafalan. Sehingga proses pembelajaran seperti ini membuat hasil belajar siswa meningkat. Selajan dengan pendapat Briggs (dalam Arsa, 2015:2) yang menyatakan bahwa hasil belajar dapat diartikan sebagai seluruh kecakapan dan hasil yang dicapai siswa melalui proses pembelajaran di sekolah yang dinyatakan dengan angka-angka atau nilai-nilai melalui tes tertentu. Siswa yang berhasil dalam kegiatan belajar adalah siswa yang berhasil mencapi tujuan pembelajaran. untuk mengetahui apakah hasil belajar telah tercapai, dapat diketahui melalu evalusi.

Penelitian lain yang mendukung adalah penelitian yang dilakukan oleh Putriani (2017), yang berjudul Pengaruh Model Pembelajaran Value Clarification Technique (VCT) Berbasis Masalah Sosial Terhadap Hasil Belajar PKn Siswa Kelas V. Dalam penelitian ini model pembelajaran VCT membuat siswa aktif dalam proses pembelajaran. Hal ini tampak ketika siswa menanggapi permasalahan yang diberikan oleh guru. Selain itu pembelajaran menggunakan model VCT yang didesain dengan membentuk kelompok kecil melatih siswa untuk bekerjasama dalam kelompok guna menyelesaikan tugas yang diberikan. Melalui kegiatan diskusi kelompok, siswa secara aktif dan antusias utuk memecahkan masalah yang dihadapi dalam proses pembelajaran. Siswa yang belum mengerti dapat bertanya langsung dengan teman kelompok sehingga menumbuhkan rasa ingin tahu siswa. VCT juga menekankan pada penanaman nilai dalam diri siswa, sehingga dalam aktivitas sehari-hari nilai tersebut akan menjadi suatu pedoman dalam bertingkah laku dan bersikap dalam menanggapi dan menyelesaikan permasalahan sosial yang bertentangan dengan norma yang berlaku di masyarakat.

Hal ini berbeda dengan pembelajaran konvensional pada kelas kontrol. Guru lebih banyak memberikan ceramah dan kurang melibatkan siswa dalam proses pembelajaran. Hal ini dapat dilihat ketika guru menjelaskan guru lebih banyak memberikan ceramah sehingga siswa menjadi pasif. Siswa lebih banyak mendengarkan apa yang disampaikan oleh guru sambil mencatat. Proses pembelajaran di kelas menjadi monoton. Sejalan dengan pendapat Degeng (dalam Agung, 2014:159) menyatakan "pembelajaran konvensional cenderung pada belajar hafalan dan menoleransi respon-respon yang bersifat konvergen, menekankan informasi konsep, latihan soal dalam teks, dan penilaian bersifat tradisional dengan paper and pensil test yang hanya menuntut pada satu jawaban benar". Setelah materi selesai disampaikan, guru memberikan evaluasi berupa penugasan. Guru meminta siswa menuliskan tugas tersebut di buku tulis. Guru juga tidak menggunakan media pembelajaran. Padahal media pembelajaran digunakan untuk memperjelas materi yang disampaikan oleh guru. Dalam kegiatan pembelajaran, proses pembelajaran seperti ini terjadi berulang-ulang sehingga pembelajaran konvensional kurang maksimal dalam meningkatkan hasil belajar siswa.

Hambatan yang ditemukan ketika dilakukan penelitian pada kelas eksperimen tidak terlalu berarti. Hanya ada beberapa hambatan kecil seperti masih terdapat beberapa siswa yang suka bercanda dalam mengikuti proses 
pembelajaran. Tetapi hal tersebut dapat ditanggulangi oleh guru dengan memberikan perhatian lebih kepada siswa yang bersangkutan. Siswa yang ribut diberikan soal oleh guru. Sementara hambatan di kelas kontrol adalah banyak ditemukan siswa yang kurang memperhatikan saat guru menjelaskan materi seperti bermain dengan teman sebangku. Selain itu terdapat pula beberapa siswa yang ketika diberikan pertanyaan oleh guru tidak bisa menjawab.

Hal ini berarti terdapat perbedaan hasil belajar PKn siswa yang mengikuti Value Clarification Technique (VCT) berbantuan media sederhana dengan siswa yang mengikuti pembelajaran konvensional di kelas III di gugus XIV kecamatan buleleng kabupaten buleleng tahun pelajaran 2017/2018.

\section{Simpulan}

Berdasarkan hasil penelitian dan pembahasan dapat disimpulkan sebagai berikut: (1) Implementasi Value Clarification Technique (VCT) berbantuan media sederhana efektif pengaruhnya terhadap hasil belajar PKn siswa kelas III di gugus XIV kecamatan buleleng kabupaten buleleng tahun pelajaran 2017/2018. Tinjauan ini didasarkan pada hasi uji t-brunning. Analisis data menggunakan uji t-brunning diketahui efektivitas size termasuk kedalam efektivitas tinggi $(0,8<4,19)$, (2) Terdapat perbedaan yang signifikan hasil belajar PKn antara siswa yang mengikuti Value Clarification Technique (VCT) berbantuan media sederhana dengan siswa yang mengikuti pembelajaran konvensional di kelas III di gugus XIV kecamatan buleleng kabupaten buleleng tahun pelajaran 2017/2018. Tinjauan ini didasarkan pada hasil uji ANAVA A dan rata-rata nilai hasil belajar siswa. Analisis menggunakan ANAVA A diketahui, $\mathrm{f}_{\text {hit }}=402,47$ dan $\mathrm{t}_{\text {tab }}=4,08$ untuk taraf signifikansi $5 \%$. Berdasarkan kriteria pengujian, karena $\mathrm{F}_{\text {hit }}>\mathrm{F}_{\text {tab }}$ maka $\mathrm{H}_{0}$ ditolak dan $\mathrm{H}_{1}$ diterima. Artinya, terdapat perbedaan yang signifikan terhadap hasil belajar PKn siswa yang mengikuti Value Clarification Technique (VCT) berbantuan media sederhana dengan siswa yang mengikuti pembelajaran konvensional di kelas III di gugus XIV kecamatan buleleng kabupaten buleleng tahun pelajaran 2017/2018. Ini berarti terdapat pengaruh positif terhadap hasil belajar PKn siswa kelas III di gugus XIV kecamatan buleleng kabupaten buleleng tahun pelajaran $2017 / 2018$.

Saran yang dapat diberikan berdasarkan penelitian yang telah dilakukan adalah sebagai berikut: (1) Siswa-siswa di sekolah dasar agar lebih aktif dalam mengikuti proses pembelajaran di kelas danhendaknya lebih mempersiapkan diri dengan cara belajar agar mampu menjawab pertanyaan yang diberikan oleh guru, (2) Kepada guru-guru hendaknya dapat menerapkan Value Clarification Technique (VCT) berbantuan media sederhana karena berpengaruh positif terhadap hasil belajar PKn, (3) Kepada sekolah hendaknya memfasilitasi menerapan Value Clarification Technique (VCT) untuk menunjang pembelajaran agar siswa semakin termotivasi untuk belajar dan mengoptimalkan hasil belajar siswa sehingga mutu sekolah menjadi meningkat. Selain itu, kepala sekolah hendaknya mendorong guru agar dapat menerapkan VCT dalam proses pembelajaran di kelas, (4) Dinas pendidikan hendaknya meningkatkan kualitas guru dengan cara memberikan workshop atau pelatihan mengenai pembelajaran inovatif agar tercipta tenaga-tenaga pendidik yang profesional, (5) Kepada peneliti lain hendaknya hasil penelitian ini dapat dijadikan kajian penelitian relevan sebagai penunjang penelitian dengan kajian yang lebih luas dan mendalam mengenai Value Clarification Technique (VCT). Peneliti lain dapat mencoba penelitian ini di mata pelajaran lain sehingga penelitian mengenai VCT akan terus dilakukan.

\section{Daftar Pustaka}

Adisusilo, Sutarjo. 2012. Pembelajaran Nilai-Karakter. 2012. Jakarta: Rajawali Pers.

Agung, A. A. G. 2014. Metodologi Penelitian. Singaraja: Aditya Media Publishing.

Hakim, dkk. 2016. Pendidikan Kewarganegaraan dalam Konteks Indonesia. Malang: Madani.

Karwono, H. dan Heni Mularsih. 2017. Belajar dan Pembelajaran serta Pemanfaatan Sumber Belajar. Depok: Rajawali Pers.

Mardenis. 2016. Pendidikan Kewarganegaraan dalam Rangka Pengembangan Kepribadian Bangsa. Jakarta: Rajawali Pers.

Ni Putu Dessy Putriani. 2017. "Pengaruh Model Pembelajaran Value Clarification Technique (VCT) Berbasis Masalah Sosial Terhadap Hasil Belajar PKN Siswa Kelas V SD Di Gugus V Kecamatan Karangasem Tahun Pelajaran 2016/2017”. Mimbar PGSD Undiksha, Volume 5. Nomor 2.

Permediknas Nomor 22 Tahun 2006. 2006. Jakarta: Departemen Pendidikan Nasional.

Subana, M. dan Sunarti. 2011. Strategi Belajar Mengajar Bahasa Indonesia Berbagai Pendekatan, Metode Teknik, dan Media Pengajaran. Bandung: Pustaka Setia.

Sugiono. 2017. Metode Penelitian Pendidikan. Bandung: Alfabeta.

Suka Arsa, I Putu. 2015. Belajar dan Pembelajaran Strategi Belajar yang Menyenangkan. Yogyakarta: Media Akademi.

Susanto, Ahmad. 2013. Teori Belajar \& Pembelajaran. Yogyakarta: Prenadamedia Group

Taniredja, Tukiran, dkk. 2011. Model-model Pembelajaran Inovatif. Bandung: Alfabeta Cv.

Tegeh, I Made. 2010. Media Pembelajaran. Singaraja: Universitas Pendidikan Ganesha. 
Wahyuni, Ayu Tri. 2014. "Pengaruh Model Pembelajaran Value Clarification Technique Berbantuan Media Cerita Bergambar Terhadap Hasil Belajae PKn Siswa Kelas V SD Gugus 1 Kecamatan Gianyar. Mimbar PGSD Undiksha, Volume 2. Nomor 1.

Wina, Sanjaya. 2006. Strategi Pembelajaran. Bandung: Prenadamedia Group. 